Zeszyty Naukowe Szkoły Głównej Gospodarstwa Wiejskiego w Warszawie

Problemy Rolnictwa Światowego tom 18 (XXXIII), zeszyt 3, 2018: 332-341

DOI: $10.22630 /$ PRS.2018.18.3.91

Monika Wojcieszak $^{1}$, Norbert Szalaty ${ }^{2}$, Weronika Wyduba ${ }^{3}$

Uniwersytet Przyrodniczy w Poznaniu

\title{
Wsparcie rolnictwa zrównoważonego w Polsce w ramach PROW 2014-2020 na przykładzie działania rolno-środowiskowo- klimatycznego
}

\section{Support for Sustainable Agriculture in Poland under RDP 2014- 2020 on the Example of Agri-Environmental-Climate Action}

\begin{abstract}
Synopsis. Producenci rolni chcac sprostać oczekiwaniom rynku coraz chętniej korzystaja z pomocy jaką oferuje Unia Europejka. W artykule podjęto próbę charakterystyki działania rolnośrodowiskowo-klimatycznego oraz przedstawiono stan wykorzystania środków unijnych w zakresie działania rolno-środowiskowo-klimatycznego. Jak wynika z przeprowadzonych analiz zauważono, iż analizowane działanie jest ważnym projektem służącym ochronie i zachowaniu naturalnych ekosystemów. Rolnicy chętnie uczestniczą w tym projekcie, gdyż otrzymują płatności w zakresie dwunastu pakietów, które służą ochronie wód, gleb, cennych siedlisk przyrodniczych, klimatu, zagrożonych gatunków ptaków, zwierząt gospodarskich, jak również ochronie różnorodności krajobrazu.
\end{abstract}

Słowa kluczowe: rolnictwo zrównoważone, PROW 2014-2020, ARiMR, producenci

\begin{abstract}
Agricultural producers, wishing to meet the expectations of the market, are increasingly eager to take advantage of the assistance offered by the European Union. The article attempts to characterize the agro-environmental and climatic activity and presents the state of use of the EU funds in the scope of the agro-environmental and climatic activity. As the analyses show, the measure under analysis is an important project aimed at protection and preservation of natural ecosystems. Farmers are keen to participate in this project as they receive payments for twelve packages that protect water, soil, valuable natural habitats, climate, endangered bird species, farm animals and landscape diversity.
\end{abstract}

Key words: sustainable agriculture, RDP 2014-2020, ARMA (Agency for Restructuring and Modernisation of Agriculture), producers

JEL Classification: Q10, Q14, Q20

\section{Wprowadzenie}

Dynamiczny rozwój gospodarczy jaki miał miejsce w drugiej połowie XX wieku wpłynął na poprawę dobrobytu w krajach rozwiniętych Ameryki Północnej czy Europy Zachodniej, ale także przyczynił się jak zauważa Żylicz, do „przyspieszonego zużycia przyrody i pauperyzacji ludności” (Żylicz, 2004; Żmija, 2014). Idea rozwoju

\footnotetext{
${ }^{1}$ dr, Katedra Ekonomii i Polityki Gospodarczej w Agrobiznesie UP w Poznaniu, ul. Wojska Polskiego 28, 60-637 Poznań, e-mail: monika.wojcieszak@up.poznan.pl; https://orcid.org/0000-0002-9962-2648

${ }^{2}$ mgr, Katedra Ekonomii i Polityki Gospodarczej w Agrobiznesie UP w Poznaniu, ul. Wojska Polskiego 28, 60-637 Poznań, e-mail: norbert.szalaty@up.poznan.pl

${ }^{3}$ mgr, Katedra Ekonomii UP w Poznaniu, ul. Wojska Polskiego 28, 60-637 Poznań,

e-mail: weronika.wyduba@up.poznan.pl
} 
zrównoważonego stanowi odpowiedź na te problemy. Mimo, iż przesłanie tej koncepcji jest zrozumiałe, to interpretacja oraz zdefiniowanie, czym jest zrównoważony rozwój, prowadzi do dyskusji, a w rezultacie do stopniowego rozszerzenia zakresu problematyki dotyczącej tej idei.

Koncepcja zrównoważonego rozwoju w odniesieniu do obszarów wiejskich i rolnictwa nabiera dodatkowego znaczenia, bowiem przy realizacji strategicznych celów uwzględnia się znaczenie przyrodniczego środowiska, gdyż w tych formach działalności, od przyrody uzależnione są uzyskane wyniki. Takim rodzajem działalności jest rolnictwo, a jego obszarem działalności są obszary wiejskie (Stanny, 2013). Z uwagi na ścisłe powiązanie rozwoju obszarów wiejskich z rozwojem rolnictwa nie można mówić o rozwoju obszarów wiejskich bez rolnictwa zrównoważonego. Idea zrównoważonego rozwoju w odniesieniu do obszarów wiejskich zakłada dodatkowo prowadzenie działalności gospodarczej na tych terenach oraz poprawę warunków życia ludności wiejskiej. Wspieranie takiej koncepcji rozwoju w rolnictwie nie wpływa na degradację środowiska, jednak umożliwia ochronę gleby, zwierząt, roślin i zasobów wodnych. Zatem jest to idea zapewniająca rolnictwo żywotność ekonomiczną przy jednoczesnej realizacji celów ekologicznych i produkcyjnych (Sydorovych, Wossink, 2008).

Rolnictwo zrównoważone, zdaniem wielu autorów (Zegar, 2005; Matuszczak, 2013) realizować powinno jednocześnie zarówno cele produkcyjne jak i ekologiczne, ekonomiczne oraz społeczne. Pomijając wymiar społeczny pozostałe są w pewnym stopniu komplementarne, jednak mogą pojawić się między nimi pewne sprzeczności. Produkcja rolnicza charakteryzująca się dużą intensywnością degraduje środowisko, mniej intensywna produkcja jest przyjazna środowisku, jednak generuje wyższe koszty, które w ostatecznym rozrachunku ponoszą konsumenci poprzez wzrost cen produktów.

W myśl definicji przedstawionej w 1987 roku przez Komisję do Spraw Środowiska i Rozwoju, zrównoważony rozwój to sposób zaspakajania potrzeb pokolenia współczesnego, w taki sposób który nie ogranicza możliwość zaspakajania potrzeb przyszłym pokoleniom (Sadowski, 2012). Kiełczewski (2009) dokonał podziału zrównoważonego rozwoju na dwa cele: sprawiedliwość międzypokoleniową i wewnątrzpokoleniową. Ta pierwsza związana była z dbałością o współczesne i przyszłe pokolenia w oparciu o świadomość zachowania naturalnego kapitału dla przyszłych generacji poprzez rozsądne gospodarowanie zasobami przyrody i zachowanie odpowiednich proporcji między inwestycjami a konsumpcją. Natomiast wewnątrzpokoleniowa sprawiedliwość uznaje dbałość o obecne pokolenia, poprzez zmniejszanie nierówności w rozwoju obszarów zacofanych i rozwiniętych, likwidację ubóstwa, analfabetyzmu i głodu.

Konieczność respektowania norm zrównoważonego rozwoju w odniesieniu do rolnictwa jest szczególnie istotna z uwagi na fakt, że intensywne rolnictwo wykorzystuje zasoby przyrody jak również wpływa na ekologiczne systemy. Zrównoważone rolnictwo nie dotyczy bowiem tylko kwestii rolnictwa jako sektora związanego z produkcją żywności, ale dotyczy całokształtu stosunków społeczno-gospodarczych w samym rolnictwie jak i poza nim. Z uwagi na społeczny wymiar odnosi się również do przestrzeni życia na obszarach wiejskich (Niewęgłowska, 2010).

Realizacja idei rozwoju zrównoważonego rolnictwa oraz obszarów wiejskich wiążę się z wieloma trudnościami zarówno o charakterze ekonomicznym (działalność inwestycyjna), socjalnym (dochody ludności wiejskiej), etycznym oraz intelektualnym (świadomość ekologiczna). Przeciwności w jej realizacji w ujęciu praktycznym wynikają często z faktu, iż jest to idea próbująca połączyć sprzeczne cele, zwłaszcza w krótszym okresie czasu. 
W reakcji na występujące sprzeczności jak wskazuje Kociszewski (2011) podjęto próby zreformowania WPR, w których coraz większą uwagę skoncentrowano na uwzględnianiu uwarunkowań środowiskowych. W dużej mierze wynikało to z rozwijanej równolegle polityki ekologicznej Unii Europejskiej, a szczególnie z przyjęcia jednej z najważniejszych jej zasad tj. integracji tej polityki z politykami sektorowymi (Kociszewski, 2011). Zastosowanie wskazanej zasady wiązało się między innymi $\mathrm{z}$ nałożeniem standardów środowiskowych na producentów rolnych w UE oraz $\mathrm{z}$ wdrażaniem stosownych instrumentów ekonomicznych w obrębie WPR. W Polsce działaniem, którego zadaniem było uwzględnienie aspektu środowiskowego w rolnictwie było uczestnictwo rolników w działaniu rolnośrodowiskowym (PROW 2007-2013). Kontynuacją powyższego programu w perspektywie PROW 2014-2020 jest działanie rolno-środowiskowoklimatyczne. Niniejsze opracowanie stanowi próbę charakterystyki i analizy wykorzystania środków unijnych w ramach działania rolno-środowiskowo-klimatycznego, które wpisuje się w koncepcje zrównoważonego rozwoju rolnictwa w tym aspektu środowiskowego.

\section{Dane i metody}

Celem artykułu była charakterystyka i analiza wykorzystania środków przez producentów rolnych w kraju w ramach ich uczestnictwa w działaniu rolno-środowiskowoklimatycznym w ramach Programu Rozwoju Obszarów Wiejskich (PROW) na lata 20142020. Opracowanie przygotowano z wykorzystaniem techniki desk research i ma ono charakter analizy, której celem jest poruszenie problematyki dofinansowania z Unii Europejskiej (UE) gospodarstw. W artykule zastosowano metodę analizy zebranego materiału. Dobór metod determinowała dostępność materiałów źródłowych, z których część miała charakter wtórny (raporty, dokumenty statystyki publicznej, literatura związana z zagadnieniem innowacyjności, problemami dofinasowania podmiotów) oraz pierwotny (niepublikowane dane Agencji Restrukturyzacji i Modernizacji Rolnictwa - ARiMR). Materiał badawczy stanowią dane pochodzące z ARiMR, dotyczące wniosków złożonych przez gospodarstwa w latach 2014-2017 o dofinasowanie w ramach działania rolnośrodowiskowo-klimatycznego w ramach PROW 2014-2020. Przedmiot badawczy stanowiła analiza aktywności polskich producentów. W artykule posłużono się metodą opisową i tabelaryczną analizy danych.

\section{Charakterystyka działania rolno-środowiskowo-klimatycznego}

Działalność prowadzona przez rolników polega w głównej mierze na produkcji żywności dobrej jakościowo oraz bezpiecznej, uwzględniając jednocześnie przede wszystkim w swojej działalności ekonomiczne uwarunkowania. Produkcja rolna bazuje na naturalnych zasobach, a jej trwałość uzależniona jest od klimatu oraz stanu środowiska. Jednym z priorytetów Wspólnej Polityki Rolnej Unii Europejskiej jest promowanie rolniczych praktyk sprzyjających ochronie środowiska. Realizacja tego celu odbywa się np. poprzez wdrażanie we wszystkich krajach członkowskich Unii działania rolnośrodowiskowo-klimatycznego. Działanie te składa się $\mathrm{z}$ pakietów, a w ich obrębie z licznych wariantów. Każdy pakiet oraz wariant obejmuje zakres działań rolniczych, których przestrzeganie sprzyja ochronie środowiska i dziedzictwa przyrodniczego. Każdy rolnik, 
w zależności od rodzaju prowadzonej produkcji czy uwarunkowań przyrodniczych, może wybrać dla siebie pakiet i wariant, którego realizacja trwa 5 lat i w efekcie otrzymać płatności. Pakiety w ramach działania rolno-środowiskowo-klimatycznego w większości przypadków są kontynuacją pakietów realizowanych w ramach Programu rolnośrodowiskowego PROW 2007-2013. W obecnej perspektywie tj. PROW 2014-2020 działanie Rolnictwo ekologiczne oraz Działanie rolno-środowiskowo-klimatyczne funkcjonują jako dwa niezależne działania, czyli inaczej niż to było w poprzednim okresie programowania, gdzie ekologiczne rolnictwo stanowiło jedno z wariantów Programu rolnośrodowiskowego.

Założeniem działania rolno-środowiskowo-klimatycznego jest promowanie zwyczajów rolniczych, które służą ochronie wód, gleb, cennych siedlisk przyrodniczych, klimatu, zagrożonych gatunków ptaków, zwierząt gospodarskich, jak również ochronie różnorodności krajobrazu. Metody praktykowane w ramach tego działania wpływają na poziom zróżnicowania różnorodności biologicznej oraz przyczyniają się do zwiększenia liczebności i różnorodności gatunkowej owadów zapylających, jednocześnie tworząc siedliska występowania innych gatunków zwierząt. Pakiety $\mathrm{w}$ ramach tego działania stwarzają pewnego rodzaju zachętę finansową dla zarządców lub rolników, którzy dobrowolnie podejmą się działalności rolniczej zgodnie z przyjętymi normami. Beneficjenci realizują działania polegające na dostosowaniu się do wymogów, które sprzyjają różnym elementom składowym środowiska naturalnego. W większości przypadków wymogi te prowadzą do utraty części zysków w wyniku stosowania praktyk przyjaznych dla środowiska, które przyczyniają się do podniesienie kosztów gospodarowania. Płatności w ramach działania rolno-środowiskowo-klimatycznego stanowią pewnego rodzaju rekompensatę utraconego dochodu oraz poniesionych dodatkowo kosztów (Ministerstwo Rolnictwa i Rozwoju Wsi, 2016).

W ramach działania ze wsparcia skorzystać może:

- rolnik prowadzący działalność rolniczą położonym na terenie Polski gospodarstwie;

- zarządca gruntów czyli osoba fizyczna, prawna, grupy osób fizycznych lub prawnych gospodarujących na przyrodniczych obszarach, czyli terenach, które nie są użytkami rolnymi,

- grupa rolników lub grupa rolników oraz zarządców gruntów.

Beneficjent decydując się skorzystać z działania rolno-środowiskowo-klimatycznego, przy pomocy rolnośrodowiskowego doradcy, przygotowuje plan działalności rolnośrodowiskowej. Zakres planu obejmuje całkowity okres zobowiązania czyli okres 5 lat. Elementami planu jest opis gospodarstwa, wskazanie pakietów, które zostaną zrealizowane, jak również przedstawienie informacji związanych $\mathrm{z}$ realizowanym zobowiązaniem dotyczącym np. terminów koszenia czy płodozmianu.

Każdy beneficjent jest sprawdzany z przestrzegania wymogów w ramach corocznie prowadzonych przez Agencje Restrukturyzacji i Modernizacji Rolnictwa kontroli administracyjnej jak również przeprowadzonej na miejscu u beneficjenta. Kontrola administracyjna polega na sprawdzeniu, czy spełnione zostały wszystkie wytyczne umożliwiające uczestnictwo w konkretnym pakiecie. Kontrola na miejscu u beneficjenta, dotyczy 5\% gospodarstw podejmujących się tego działania. Umożliwia ona na sprawdzenie, czy obowiązki danego pakietu zostały przestrzegane. Wszystkie pakiety w ramach Działania rolno-środowiskowo-klimatycznego są wieloletnimi pakietami, oznacza to, że beneficjent podejmuje się zobowiązania przez okres 5 lat. 


\section{Wyniki badań}

Rozwój rolnictwa zrównoważonego wspierany jest ze środków pochodzących z Programu Rozwoju Obszarów Wiejskich, który finansowany jest z Europejskiego Funduszu Rolnego na Rzecz Rozwoju Obszarów Wiejskich i współfinansowanego z krajowego budżetu. W ramach PROW 2007-2013 były uruchomione trzy działania, w zakresie których producenci kwalifikowali się do wsparcia m.in.: Program rolnośrodowiskowy, Uczestnictwo rolników w systemach jakości żywności i Działania informacyjne i promocyjne. W ramach programu rolnośrodowiskowego zrealizowano płatności na kwotę 1328892 129, 96 zł (stan na koniec 2013). Łączna powierzchnia wsparcia, z pozytywnie wydanych decyzji wyniosła 654390,68 ha. Analizując konkretne pakiety można zauważyć, że największym zainteresowaniem cieszył się wówczas wariant 2.1 Uprawy rolnicze (Ministerstwo Rolnictwa i Rozwoju Wsi, 2014). Kontynuacja programu rolnośrodowiskowego w ramach PROW 2014-2020 jest działanie rolnośrodowiskowo-klimatyczne. Głównym celem tego działania jak wcześniej wskazano jest wsparcie rolników, którzy zobowiązują się utrzymać bądź przejść na metody oraz praktyki ekologicznego rolnictwa, które określone zostały w rozporządzeniu Rady nr 834/2007 z 2007 roku. Dotacje w zakresie tego działania obejmują dwa poddziałania to jest: płatności podczas konwencji na ekologiczne rolnictwo oraz płatności umożliwiające utrzymanie ekologicznego rolnictwa. W ramach funkcjonowania działania rolno-środowiskowoklimatycznego obowiązuje degresywność, która uzależniona jest od łącznej powierzchni objętej konkretnym wsparciem. Wyróżnia się następujące progi degresywności:

- $\quad$ do powierzchni nie przekraczającej 50 ha jest udzielana pomoc w wysokości 100\% stawki;

- za każdy kolejny hektar powierzchni pomiędzy 50 ha a 100 ha przyznawana jest pomoc w wysokości 75\% stawki;

- $\quad$ za każdy kolejny hektar powyżej 100 ha przyznawana jest pomoc w wysokości 60\%".

Dotacje przyznane w ramach działania Rolno-środowiskowo-klimatycznego nie moga zostać udzielone na zobowiązania w zakresie działania Rolnictwo ekologiczne. Jedno gospodarstwo może uzyskać wsparcie na oba działania, pod warunkiem, że ich realizacja odbędzie się na innej powierzchni. Wyjątek stanowi realizacja Pakietu Rolnictwa zrównoważonego, ponieważ $\mathrm{w}$ tym wypadku beneficjent zobowiązuje się na realizacje działania na obszarze całego gospodarstwa, co uniemożliwia realizację działania Rolnictwo ekologiczne. Analizując poziom wsparcia w Polsce na poszczególne pakiety (tab. 1) można zauważyć, iż wsparciem objętym zostało 7173 gospodarstw, których łączna powierzchnia stanowiła 180321 ha. Pula środków wyniosła 212452 352,62 zł, z czego ponad 63,63\% to pieniądze pochodzące z EFRROW (135 183 315,00 zł).

Producenci rolni, którzy aplikowali o środki unijne po okresie konwersji stanowili większość tj. 65,92\%. Pomocą objętych zostało 4729 gospodarstw ekologicznych, z czego obszar pomocy stanowił 112593 ha. Wydatkowano kwotę na poziomie 124170 011,33 zł, z czego środki z EFRROW stanowiły 62,63\%. Z kolei 3435 gospodarstw, to gospodarstwa, które przestawiały się na produkcję metodami ekologicznymi. Obszar objęty pomocą wyniósł 67728 ha. Środki finansowe przeznaczone na działania w okresie konwersji opiewały na kotwę 88282341,29 zł. 
Tabela 1. Poziom wsparcia gospodarstw ekologicznych z podziałem na poszczególne pakiety (produkcja roślinna) w okresie 2014-2017

Table 1. Level of support for organic farms by individual packages (vegetal production) from 2014-2017

\begin{tabular}{|c|c|c|c|c|c|}
\hline Pakiet & Wyszczególnienie & $\begin{array}{c}\text { Liczba } \\
\text { wspieranych } \\
\text { gospodarstw } \\
\text { (szt.) }\end{array}$ & $\begin{array}{l}\text { Obszar objetty } \\
\text { wsparciem } \\
\text { (ha) }\end{array}$ & $\begin{array}{l}\text { EFRROW } \\
\text { (zł) }\end{array}$ & $\begin{array}{l}\text { Ogółem } \\
\text { (zł) }\end{array}$ \\
\hline Pakiet 1. & $\begin{array}{l}\text { Uprawy rolnicze w okresie } \\
\text { konwersji }\end{array}$ & 1959 & 27558 & 21027901,19 & 33047170,47 \\
\hline Pakiet 7. & $\begin{array}{l}\text { Uprawy rolnicze po okresie } \\
\text { konwersji }\end{array}$ & 3054 & 49896 & 34958145,84 & 54939758,89 \\
\hline & Razem & 4550 & 77455 & 55986047,03 & 87986929,36 \\
\hline Pakiet 2. & $\begin{array}{l}\text { Uprawy warzywne w okresie } \\
\text { konwersji }\end{array}$ & 997 & 14938 & 16820404,69 & 26434718,43 \\
\hline Pakiet 8. & $\begin{array}{l}\text { Uprawy warzywne po okresie } \\
\text { konwersji }\end{array}$ & 1664 & 13534 & 13845377,76 & 21759216,93 \\
\hline & Razem & 2532 & 28472 & 30665782,45 & 48193935,36 \\
\hline Pakiet 3. & $\begin{array}{l}\text { Uprawy zielarskie w okresie } \\
\text { konwersji }\end{array}$ & 131 & 2218 & 1987532,73 & 3123579,16 \\
\hline Pakiet 9. & $\begin{array}{l}\text { Uprawy zielarskie po okresie } \\
\text { konwersji }\end{array}$ & 162 & 2891 & 2519891,89 & 3960227,62 \\
\hline & Razem & 277 & 5110 & 4507424,62 & 7083806,78 \\
\hline Pakiet 4. & $\begin{array}{l}\text { Uprawy sadownicze w okresie } \\
\text { konwersji - wariant podstawowe } \\
\text { uprawy sadownicze }\end{array}$ & 498 & 2379 & 3873820,32 & 6088047,42 \\
\hline Pakiet 10. & $\begin{array}{l}\text { Uprawy sadownicze po okresie } \\
\text { konwersji - wariant podstawowe } \\
\text { uprawy sadownicze }\end{array}$ & 1134 & 4299 & 6881352,43 & 10814652,40 \\
\hline & Razem & 1516 & 6678 & 10755172,75 & 16902699,82 \\
\hline Pakiet 4. & $\begin{array}{l}\text { Uprawy sadownicze w okresie } \\
\text { konwersji - wariant ekstensywne } \\
\text { uprawy sadownicze }\end{array}$ & 89 & 374 & 270775,10 & 425547,08 \\
\hline Pakiet 10. & $\begin{array}{l}\text { Uprawy sadownicze po okresie } \\
\text { konwersji - wariant ekstensywne } \\
\text { uprawy sadownicze }\end{array}$ & 202 & 966 & 674654,99 & 1060280,71 \\
\hline & Razem & 278 & 1340 & 945430,09 & 1485827,79 \\
\hline Pakiet 5. & $\begin{array}{l}\text { Uprawy paszowe na gruntach } \\
\text { ornych w okresie konwersji }\end{array}$ & 1249 & 15258 & 10103408,83 & 15878386,93 \\
\hline Pakiet 11. & $\begin{array}{l}\text { Uprawy paszowe na gruntach } \\
\text { ornych po okresie konwersji }\end{array}$ & 2129 & 29015 & 14973326,01 & 23531890,49 \\
\hline & Razem & 3082 & 44273 & 25076734,84 & 39410277,42 \\
\hline Pakiet 6. & $\begin{array}{l}\text { Trwałe użytki zielone w okresie } \\
\text { konwersji }\end{array}$ & 736 & 5002 & 2090171,27 & 3284891,80 \\
\hline Pakiet 12. & $\begin{array}{l}\text { Trwałe użytki zielone po okresie } \\
\text { konwersji }\end{array}$ & 1661 & 11992 & 5156551,95 & 8103984,29 \\
\hline Razem & & 2230 & 16994 & 7246723,22 & 11388876,09 \\
\hline Suma w okr & sie konwersji & 3435 & 67728 & 56174014,13 & 88282341,29 \\
\hline Suma po ok & sie konwersji & 4729 & 112593 & 79009300,87 & 124170011,33 \\
\hline Suma razen & & 7173 & 180321 & 135183315,00 & 212452352,62 \\
\hline
\end{tabular}

Źródło: opracowanie własne na podstawie niepublikowanych danych z ARiMR. 
W przypadku produkcji roślinnej wyróżnić można siedem obszarów wsparcia gospodarstw ekologicznych tj. Uprawy rolnicze w/po okresie konwersji (pakiet 1 i 7), Uprawy warzywne w/po okresie konwersji (pakiet 2 i 8), Uprawy zielarskie w/po okresie konwersji (pakiet 3 i 9), Uprawy sadownicze w/po okresie konwersji - wariant podstawowe uprawy sadownicze (pakiet 4 i 10), Uprawy sadownicze w/po okresie konwersji - wariant ekstensywne uprawy sadownicze (pakiet 4 i 10), Uprawy sadownicze na gruntach ornych w/po okresie konwersji (pakiet 5 i 11) oraz Trwałe użytki zielone w/po okresie konwersji (pakiet 6 i 12). W Polsce najbardziej popularnym obszarem wsparcia z którego korzystaja rolnicy jest pakiet 1 i 7, który dotyczy upraw rolniczych w/po okresie konwersji. Łącznie pomoc otrzymało $63,43 \%$ beneficjentów w stosunku do ogółu gospodarstw ekologicznych. Ponad $67 \%$ (tj. 3054) to gospodarstwa, które otrzymały wsparcie w ramach pakietu 7, czyli w celu promowania prowadzenia produkcji metodami ekologicznymi. Drugim popularnym obszarem, z którego korzystają rolnicy jest obszar Uprawy paszowe na gruntach ornych w/po okresie konwersji. W obrębie analizowanego obszaru ponad 42,96\% beneficjentów aplikowało o środki unijne w stosunku do ogółu. Ponad 69\% gospodarstw wybrało pakiet 11. Łącznie pomoc otrzymało 2129 producentów, z czego obszar pomocy obejmował 29015 ha, a środki finansowe wyniosły 23531 890,49 zł. Uprawy warzywne w/po okresie konwersji czyli pakiet 2 i 8 to trzeci obszar, w którym chętnie uczestniczą gospodarstwa (ponad 35,29\% gospodarstw uczestniczyło w tym obszarze). Łączna powierzchnia objęta pomocą wyniosła 28742 ha. Środki unijne skierowane w obrębie tych pakietów wyniosły 48193935,36 zł. Ponad 65\% to gospodarstwa, które deklarowały i uczestniczyły w pakiecie 8 , czyli były to gospodarstwa po okresie konwersji. Blisko $31 \%$ gospodarstw wskazało, iż pakiet 6 i 12, który dotyczył trwałych użytków zielonych w/po okresie konwersji, to obszar w którym otrzymali środki unijne, z czego $74,48 \%$ to beneficjenci który otrzymali środki w ramach pakietu 12 . Łącznie gospodarstwa otrzymały kwotę 11 388 876,09 zł, z czego środki z EFRROW stanowiły blisko 63\%. Do pakietu 4 i 10 Uprawy sadownicze w/po okresie konwersji - wariant ekstensywne uprawy sadownicze oraz pakietu 3 i 9 (czyli Uprawy zielarskie w/po okresie konwersji) przystapiło zaledwie odpowiednio $3,87 \%$ (uprawy sadownicze) i 3,86\% (uprawy zielarskie) rolników. Beneficjenci po okresie konwersji otrzymali większą pulę środków, z uwagi na to, iż o dotację aplikowała większa liczba producentów rolnych. Pakiet dotyczący obszaru upraw zielarski tj. 3 i 9 uprawiany był na powierzchni 5110 ha. Łącznie rolnicy otrzymali pomoc w wysokości 7083806,78 zł, z czego beneficjenci po okresie konwersji stanowili ponad 55\%. Z kolei pakiet 4 i 10 dotyczący upraw sadowniczych realizowany był na powierzchni 1340 ha. Kwota udzielonej pomocy to 1485827,79 zł. Analizując gospodarstwa $\mathrm{z}$ podziałem na poszczególne pakiety w przypadku produkcji zwierzęcej (tab. 2) można zauważyć, iż rolnicy mogli uczestniczyć w czterech pakietach tj. Pakiet 5 - Uprawy paszowe na gruntach ornych w okresie konwersji, Pakiet 11 - Uprawy paszowe na gruntach ornych po okresie konwersji, Pakiet 6 - Trwałe użytki zielone w okresie konwersji oraz Pakiet 12 - Trwałe użytki zielone po okresie konwersji. W ramach pakietu 5 liczba zwierząt utrzymywanych zgodnie z przepisami dot. rolnictwa ekologicznego stanowiła $10,81 \% \mathrm{w}$ stosunku do liczby zwierząt w gospodarstwach. Pomoc finansową otrzymało 959 gospodarstw ekologicznych. Analizując grupy zwierząt można zauważyć, iż w okresie konwersji beneficjenci najczęściej hodowali: bydło domowe, owce, świnie, daniele, króliki, kury, gęsi i kaczki. W przypadku Pakietu 11 po okresie konwersji pomoc otrzymało 1724 gospodarstw, w których łącznie hodowano zgodnie z przepisami 126063 sztuk zwierząt i były to następujące zwierzęta: bydło domowe, owce, świnie, daniele, gęsi, kaczki, kury i perlice. 
Tabela 2. Zestawienie liczby zwierząt objętych wsparciem działania rolno-środowiskowo- klimatycznego w okresie 2014-2017

Table 2. Summary of the number animals covered by agro-environment-climate support from 2014 to 2017

\begin{tabular}{|c|c|c|c|c|c|}
\hline \multicolumn{2}{|c|}{ Wyszczególnienie } & $\begin{array}{c}\text { Liczba zwierząt } \\
\text { w } \\
\text { gospodarstwach }\end{array}$ & $\begin{array}{c}\text { Liczba zwierząt } \\
\text { utrzymywanych zgodnie } \\
\text { z przepisami dot. } \\
\text { rolnictwa ekologicznego }\end{array}$ & $\begin{array}{c}\text { Liczba } \\
\text { wspieranych } \\
\text { gospodarstw } \\
\text { rolnych }\end{array}$ & $\begin{array}{l}\text { Średnia } \\
\text { wielkość } \\
\text { stada }\end{array}$ \\
\hline \multirow{14}{*}{$\begin{array}{l}\text { Pakiet } 5 . \\
\text { Uprawy } \\
\text { paszowe } \\
\text { na } \\
\text { gruntach } \\
\text { ornych w } \\
\text { okresie } \\
\text { konwersji. }\end{array}$} & bydło domowe & 26076 & 989 & 837 & 31 \\
\hline & konie & 473 & - & 59 & 8 \\
\hline & świnie & 3600 & 283 & 86 & 42 \\
\hline & owce & 2803 & 338 & 38 & 74 \\
\hline & kozy & 200 & 1 & 24 & 8 \\
\hline & daniele & 424 & 266 & 9 & 47 \\
\hline & jelenie szlachetne, sika & 1248 & 148 & 4 & 312 \\
\hline & króliki & 456 & 344 & 29 & 16 \\
\hline & gęsi & 7974 & 198 & 37 & 216 \\
\hline & indyki & 10295 & 72 & 24 & 429 \\
\hline & kaczki & 822 & 469 & 56 & 15 \\
\hline & kury & 112798 & 14899 & 255 & 442 \\
\hline & perlice & 119 & 87 & 16 & 7 \\
\hline & OGÓŁEM & 167288 & 18094 & 959 & \\
\hline \multirow{14}{*}{$\begin{array}{l}\text { Pakiet } 11 . \\
\text { Uprawy } \\
\text { paszowe } \\
\text { na } \\
\text { gruntach } \\
\text { ornych po } \\
\text { okresie } \\
\text { konwersji. }\end{array}$} & bydło domowe & 37759 & 3963 & 1482 & 25 \\
\hline & konie & 1162 & - & 114 & 10 \\
\hline & świnie & 5677 & 928 & 202 & 28 \\
\hline & owce & 12801 & 1143 & 127 & 101 \\
\hline & kozy & 953 & 86 & 75 & 13 \\
\hline & daniele & 1176 & 574 & 16 & 73 \\
\hline & jelenie szlachetne, sika & 487 & 405 & 5 & 97 \\
\hline & króliki & 1503 & 1087 & 79 & 19 \\
\hline & gęsi & 34276 & 10626 & 72 & 476 \\
\hline & indyki & 35249 & 188 & 32 & 1102 \\
\hline & kaczki & 5200 & 4441 & 130 & 40 \\
\hline & kury & 142334 & 100530 & 632 & 225 \\
\hline & perlice & 2202 & 2091 & 29 & 76 \\
\hline & OGÓŁEM & 280777 & 126063 & 1784 & \\
\hline \multirow{9}{*}{$\begin{array}{l}\text { Pakiet } 6 \text {. } \\
\text { Trwałe } \\
\text { użytki } \\
\text { zielone w } \\
\text { okresie } \\
\text { konwersji. }\end{array}$} & bydło domowe & 16026 & 1093 & 586 & 27 \\
\hline & konie & 301 & - & 40 & 8 \\
\hline & owce & 2273 & 398 & 35 & 65 \\
\hline & kozy & 329 & 7 & 25 & 13 \\
\hline & daniele & 255 & 119 & 6 & 43 \\
\hline & jelenie szlachetne, sika & 10 & 10 & 1 & 10 \\
\hline & króliki & 6206 & 6071 & 21 & 296 \\
\hline & gęsi & 2907 & 317 & 25 & 116 \\
\hline & OGÓŁEM & 28308 & 8016 & 651 & \\
\hline \multirow{10}{*}{$\begin{array}{l}\text { Pakiet } 12 \text {. } \\
\text { Trwałe } \\
\text { użytki } \\
\text { zielone po } \\
\text { okresie } \\
\text { konwersji. }\end{array}$} & bydło domowe & 30945 & 4319 & 1374 & 23 \\
\hline & konie & 869 & - & 94 & 9 \\
\hline & owce & 8620 & 1180 & 121 & 71 \\
\hline & kozy & 946 & 164 & 81 & 12 \\
\hline & daniele & 900 & 557 & 14 & 64 \\
\hline & jelenie szlachetne, sika & 424 & 345 & 5 & 85 \\
\hline & króliki & 1196 & 782 & 68 & 18 \\
\hline & gęsi & 16833 & 4028 & 65 & 259 \\
\hline & OGÓŁEM & 60733 & 11375 & 1555 & \\
\hline & SUMA & & & 3108 & \\
\hline
\end{tabular}

Źródło: opracowanie własne na podstawie niepublikowanych danych z ARiMR. 
Kolejne dwa pakiety tj. 6 i 12 dotyczą trwałych użytków rolnych w/po okresie konwersji. Po okresie konwersji środki finansowe otrzymało 1555 gospodarstw, natomiast w trakcie konwersji 651. Bydło domowe, owce, daniele i króliki to zwierzęta, które głównie hodowane były przez rolników w ramach tych dwóch pakietów.

\section{Podsumowanie}

Od początku funkcjonowania Wspólnej Polityki Rolnej koncentrowano się wówczas głównie na kluczowych kwestiach dotyczących stabilizacji rynku, zapewnienia bezpieczeństwa dostaw żywności, odpowiednio wysokich dochodów rolników i niskich cen dla konsumentów. Nie wszystkie z zamierzonych celów udało się osiagnaćć, ponieważ zaczęły powstawać tzw. efekty uboczne, które postrzegane były jako przejaw kryzysu europejskiego rolnictwa w trzech wymiarach: ekonomicznym, społecznym oraz ekologicznym. Powstanie kryzysu ekologicznego wiązało się wywołaną przez politykę WPR industrializacją rolnictwa. Wpływała ona w głównej mierze na generowaniu negatywnych efektów zewnętrznych. Powstawały one wskutek m.in. stosowania środków ochrony roślin, tworzenia monokultur uprawnych, nadmiernego poziomu nawożenia oraz niszczenia naturalnych i półnaturalnych elementów przyrody obszarów wiejskich. Straty w środowisku wpływały przede wszystkim na pogarszanie się jakości wód, ograniczeniem różnorodności biologicznej, degradacją gleb oraz niekorzystnymi zmianami klimatycznymi. Unia Europejska wychodząc naprzeciw tym niekorzystnym zmianom w celu zapewnienia środowiska i naturalnego dziedzictwa zaproponowała w ramach PROW 20077-2013 oraz PROW 2014-2020 programy, dzięki którym rolnicy mogą uczestniczyć w dobrowolnych, dodatkowych programach tzw. rolnośrodowiskowych. Jednym z działań, które wspiera ochronę środowiska naturalnego i jego ekosystemów jest działanie rolno-środowiskowoklimatyczne realizowane w PROW 2014-2020. W analizowanych latach 2014-2017 wnioski o pomoc w ramach badanego działania złożyło 7173 gospodarstw ekologicznych. Łącznie powierzchnia ekologicznej produkcji roślinnej wynosiła 180321 ha. Pula środków skierowana dla gospodarstw to $212452352,62 \mathrm{zl}$, z czego ponad $63,63 \%$ to pieniądze pochodzące z EFRROW (135 183315 zł). W przypadku produkcji zwierzęcej pomoc otrzymało 3108 gospodarstw. Rolnicy uczestniczyli w czterech pakietach, tj. Pakiet 5 Uprawy paszowe na gruntach ornych w okresie konwersji, Pakiet 11 - Uprawy paszowe na gruntach ornych po okresie konwersji, Pakiet 6 - Trwałe użytki zielone w okresie konwersji oraz Pakiet 12 - Trwałe użytki zielone po okresie konwersji. Liczba zwierząt utrzymywanych zgodnie $\mathrm{z}$ przepisami rolnictwa ekologicznego $\mathrm{w}$ analizowanym okresie wyniosła 11375 , z czego bydło domowe to grupa zwierząt, która była najczęściej hodowana w gospodarstwach rolnych.

\section{Literatura}

Adamowicz, M. (2000). Rola polityki agrarnej w zrównoważonym rozwoju obszarów wiejskich (The role of agrarian policy in sustainable rural development). Roczniki Naukowe SERiA, 2(1), 69-81.

Baer-Nawrocka, A., Szalaty, N. (2017). Produkty ekologiczne w opinii producentów i konsumentów - studium przypadku (Organic products according to producers and consumers - case study). Zagadnienia Ekonomiki Rolnej, 4, 138-153. 
Działanie rolno-środowiskowo-klimatyczne PROW 2014-2020 (Agro-environmental and climate measure RDP 2014-2020). W: Facts and figures on organic agriculture in the European Union (2016). European Commission, Agriculture and Rural Development. Pobrane 20 listopada 2017 z: http://ec.europa.eu/ agriculture/rica/pdf/Organic 2016 web new.pdf

Kiełczewski, D. (2009). Rozwój zrównoważony w skali regionalnej. Środowisko przyrodnicze - czynnik czy bariera rozwoju?(Sustainable development on a regional scale. Natural environment - a factor or a barrier to development). W: Skup M. (red.), Zrównoważony rozwój - aspekty rozwoju społeczności lokalnych (Sustainable development - aspects of local community development). Fundacja Forum Inicjatyw Rozwojowych, Białystok.

Kociszewski, K. (2011). Środowiskowe aspekty planowanej reformy wspólnej polityki rolnej (Environmental aspects of the planned reform of the common agricultural policy). Roczniki Nauk Rolniczych. Seria G, Ekonomika Rolnictwa, 98(3), 84-99.

Matuszczak, A. (2013). Zróżnicowanie rozwoju rolnictwa w regionach Unii Europejskiej w aspekcie jego zrównoważenia (Diversification of agricultural development in the regions of the European Union in terms of its sustainability). Wydawnictwo Naukowe PWN, Warszawa.

Ministerstwo Rolnictwa i Rozwoju Wsi (2014). Sprawozdanie z realizacji Programu Rozwoju Obszarów Wiejskich na lata 207-2014 (Report on the implementation of the Rural Development Programme for the years 2007-2014). Warszawa.

Ministerstwo Rolnictwa i Rozwoju Wsi (2016). Przewodnik po działaniu rolno-środowiskowo-klimatycznym PROW 2014-2020 (Guide to agrienvironmental and climatic measures RDP 2014-2020). Warszawa.

Niewęgłowska, G., (red.) (2010). Analiza możliwości wykorzystania wskaźników powiązanych z produkcją zaproponowanych przez Komisje Europejska (KE) oraz zaproponowanie wskaźników specyficznych dla produkcji rolnej w Polsce w ramach delimitacji obszarów ONW w 2010 r. (Analysis of the possibility of using production-related indicators proposed by the European Commission (EC) and proposing indicators specific to agricultural production in Poland within the delimitation of LFAs in 2010). Ekspertyza wykonana dla MRiRW, IERiGŻ - PIB, Warszawa.

Rolnictwo ekologiczne w PROW 2014-2020 (Organic farming in RDP 2014-2020). Pobrane 17 listopada 2017 z: http://www.arimr.gov.pl/pomoc-unijna/prow-2014-2020/dzialanie-rolno-srodowiskowo-klimatyczne-orazrolnictwo-ekologiczne-w-2015-roku-prow-2014-2020.html.

Sadowski, A. (2012). Zrównoważony rozwój gospodarstw rolnych z uwzględnieniem wpływu wspólnej polityki rolnej Unii Europejskiej (Sustainable development of agricultural holdings taking into account the impact of the European Union's common agricultural policy). Rozprawy Naukowe 447, Wydawnictwo Uniwersytetu Przyrodniczego w Poznaniu, Poznań.

Stanny, M. (2013). Przestrzenne zróżnicowanie rozwoju obszarów wiejskich w Polsce (Spatial diversification of rural development in Poland). Instytut Rozwoju Wsi i Rolnictwa Polskiej Akademii Nauk, Warszawa.

Sydorovych, O., Wossink, A. (2008). The Meaning of Agricultural Sustainability: Evidence From a Conjoint Choice Survey. Agricultural Systems, 98(1), 10-20.

Zegar, J.S. (2005). Koncepcja badań nad rolnictwem społecznie zrównoważonym (Concept of research on socially sustainable agriculture). W: Koncepcja badań nad rolnictwem społecznie zrównoważonym (red.) J.S. Zegar, nr 11, IERiGŻ, Warszawa, 9-22

Żmija, D. (2014). Zrównoważony rozwój rolnictwa i obszarów wiejskich w Polsce (Sustainable development of agriculture and rural areas in Poland), Studia Ekonomiczne / Uniwersytet Ekonomiczny w Katowicach, 166, $149-158$.

Żylicz, T. (2004). Ekonomia środowiska i zasobów naturalnych (Economics of the environment and natural resources). PWE, Warszawa.

Do cytowania / For citation:

Wojcieszak M., Szalaty N., Wyduba W. (2018). Wsparcie rolnictwa zrównoważonego w Polsce w ramach PROW 2014-2020 na przykładzie działania rolno-środowiskowo-klimatycznego. Problemy Rolnictwa Światowego, 18(3), 332-341; DOI: 10.22630/PRS.2018.18.3.91

Wojcieszak M., Szalaty N., Wyduba W. (2018). Support for Sustainable Agriculture in Poland under RDP 2014-2020 on the Example of Agri-Environmental-Climate Action (in Polish). Problems of World Agriculture, 18(3), 332-341; DOI: 10.22630/PRS.2018.18.3.91 